\title{
Book review: Archaeological Concepts, Techniques, and Terminology for American Prehistoric Lithic Technology
}

\author{
Harry J. Lerner \\ Université Laval, Quebec, Quebec, Canada. Email: harry.lerner.1@ulaval.ca
}

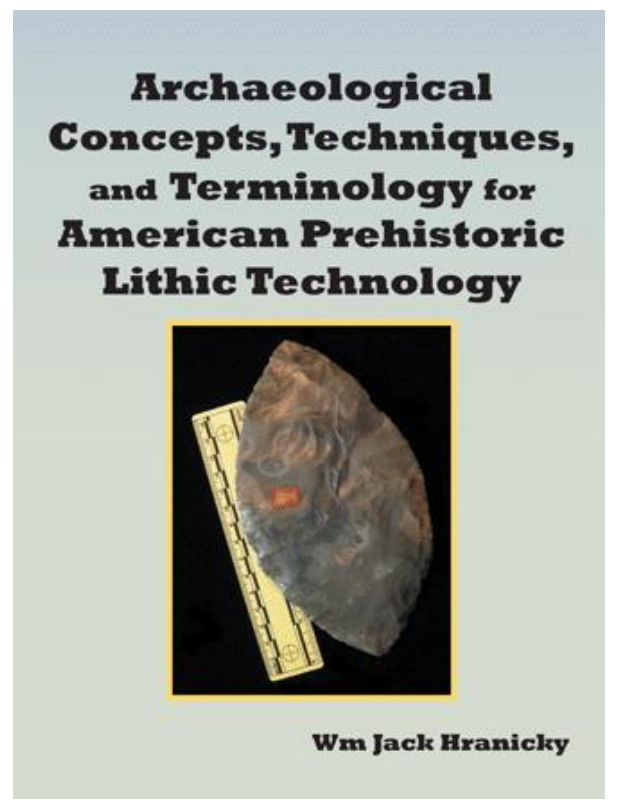

Archaeological Concepts, Techniques, and Terminology for American Prehistoric Lithic Technology

by Wm. Jack Hranicky

AuthorHouse, Bloomington, Indiana, 2013, pp. 611, ISBN 978-1-4817-5173-5

http://bookstore.authorhouse.com/Products/SKU-000628731/Archaeological-Concepts-Techniquesand-Terminology-for-American-Prehistoric-Lithic-Technology.aspx

Wm. Jack Hranicky's book Archaeological Concepts, Techniques, and Terminology for American Prehistoric Lithic Technology is a thorough and comprehensive compendium of all things lithic in North America. This book was originally published in 1986 as Dictionary of Terms for American Prehistoric Projectile Points (Special Publication No. 15, Archaeological Society of Virginia), then revised and expanded in 2004 as An Encyclopedia of Terminology and Concepts for American Prehistoric Lithic Technology (AuthorHouse).

Published by the School of History, Classics and Archaeology, University of Edinburgh ISSN: 2055-0472. URL: http://journals.ed.ac.uk/lithicstudies/

This work is licensed under a Creative Commons Attribution 2.5 UK: Scotland License. 
This third iteration is a truly exhaustive reference work that is organized into two basic sections, an introduction to the discipline in general and to lithic research in particular, followed by an alphabetical listing of terms, techniques, and methodologies of interest to any lithic analyst.

The background section, occupying the first 70 pages, covers a wide variety of fundamental issues and questions, including: defining archaeology, the role of archaeology in the modern world, the concept of prehistory, conducting archaeological research, ecology and environment in archaeology, ethics in archaeology, the nature of technology in both theory and practice, history of lithic research, study of lithic technology, classification of lithic technology, defining tool types, tool types as culture history, role of Native Americans in archaeological thought and practice, people that do archaeology and the reasons that they do it, and many others.

The rest of the volume is an exhaustive alphabetical listing of concepts, terms, procedures, and principles that have, and continue to, inform lithic research across North America. The entries cover everything from basic definitions (e.g., chert, core, flake, etc.) to more advanced concepts (e.g., line of motion, means-end analysis, ocicular point, etc.)

This publication is designed to provide as full and diverse an analytical toolkit as possible for lithic researchers of all stripes. The author himself points out that this volume is not a 'how-to' manual but rather a comprehensive resource for describing the myriad concepts, techniques, and methods commonly used in lithic research. It is also aimed at as wide an audience as possible. It is geared to be an equally useful aid to academics, avocationalists, hobbyists, or anyone interested in lithic technology.

Although there is a tendency towards colloquialism in some of the phrasing, the considerable scope of this volume certainly makes up for any perceived informality. It offers a general overview of the origins and subsequent evolution of lithic analysis, highlighting both its limits and potential. It does not shy away from the many intrinsic complexities of archaeological inquiry, but its purpose is not to offer any easy answers to the many difficult issues routinely faced by lithic analysts. Rather, it serves up all options open to researchers so that they can make fully informed decisions in designing their individual studies. Hranicky does not offer any opinions or judgements, merely the kind of facts and information necessary to carry out proper lithic research.

Overall, Archaeological Concepts, Techniques, and Terminology for American Prehistoric Lithic Technology, is a useful reference work that should have a place in any archaeological library with a bias towards lithic analysis. 